\title{
PENGARUH KUALITAS PRODUK PARIWISATA TERHADAP KEPUTUSAN BERKUNJUNG DI BALE SENI BARLI-KOTA BARU PARAHYANGAN
}

\author{
Vany Octaviany \\ Telkom University, D3 Pehotelan Fakultas Ilmu Terapan: \\ vany@tass.telkomuniversity.ac.id
}

\begin{abstract}
ABSTRAK
Jumlah kunjungan wisatawan ke Bale Seni Barli Kota Baru Parahyangan pada tahun 2013 merupakan jumlah kunjunan paling tinggi, yaitu mencapai 11.623 atau meningkat sebesar $44,2 \%$ dari tahun sebelumnya. Hal tersebut menjadi menjadi landasan bagi pihak pengelola untuk menetapkan target kunjungan yang lebih besar yaitu wisatawan diharapkan mencapai 15.000 wisatawan pada tahun selanjutnya. Akan tetapi, pada tahun 2014 peningkatan yang terjadi hanya sebesar 29\%. Sehingga diperlukan strategi yang tepat untuk mengatasi jumlah kunjungan wisatawan yang fluktuatif tersebut. Salah satu strategi yang ditempuh pihak pengelola adalah dengan meningkatkan kualitas produk pariwisata yang dimiliki. Kualitas produk pariwisata menjadi salah satu referensi bagi wisatawan dalam memilih destinasi wisata yang akan dituju yang kemudian dapat mempengaruhi keputusan wisatawan untuk berkunjung. Penelitian ini bertujuan untuk mengetahui seberapa besar pengaruh kualitas produk terhadap keputusan berkunjung wisatawan di Bale Seni Barli-Kota Baru Parahyangan. Jenis penelitian ini merupakan penelitian deskriftif dan verifikatif. Metode penelitian yang digunakan adalah Explanatory Survey, dengan jumlah sample 100 responden, sedangkan teknik analisis data menggunakan regresi sederhana. Hasil penelitian menunjukan bahwa pengaruh kualitas produk terhadap keputusan berkunjung yaitu sebesar $69 \%$, dan sisanya yaitu sebesar $31 \%$ dipengaruhi oleh faktor lain. Hal ini menunjukan bahwa kualitas produk pariwisata mampu memberikan kontribusi yang positif terhadap keputusan berkunjung.
\end{abstract}

Kata kunci: Kualitas Produk Pariwisata, Keputusan Berkunjung dan Bale Seni Barli-Kota Baru Parahyangan 


\title{
THE EFFECT OF TOURISM QUALITY PRODUCT TOWARDS DECISION TO VISIT BALE SENI BARLI-KOTA BARU PARAHYANGAN
}

\begin{abstract}
The highest number of tourists visiting Bale Seni Barli, Kota Baru Parahyangan was recorded in 2013 with 11,623 visitors, or increased by $44.2 \%$ from the previous year. This encouraged the manager to set a higher target with 15,000 visitors in the next year. Nevertheless, in 2014 the increase was only $29 \%$. Therefore, a proper strategy was needed to cope with the fluctuating number of tourist visits. One of the strategies taken by the manager was improving the quality of tourism products. Tourism product quality serves as a reference for tourists in choosing a destination, which then affects their decision to visit. This study was aimed at finding out the effect of product quality on the tourists' decision to visit Bale Seni Barli, Kota Baru Parahyangan. This study was a descriptive and verificative study. The study method employed an explanatory survey with a sample size of 100 respondents, while the data analysis used simple regression technique. The study results showed that the influence of product quality on the decision to visit was $69 \%$, while the remaining $31 \%$ were influenced by other factors. This suggests that the quality of tourism products is able to contribute positively to the decision to visit.
\end{abstract}

Keywords: Tourism Products Quality, Visiting Decision and Bale Barli-Kota Baru Parahyangan

\section{PENDAHULUAN}

Tingginya jumlah kunjungan wisatawan ke Bale Seni Barli-Kota Baru Parahyangan ada tahun 2013 yaitu 11.623 wisatawan, menjadi landasan bagi pihak pengelola untuk menetapkan target sebanyak 15.000 wisatawan pada tahun 2014 atau sebesar 29\%. Akan tetapi target tersebut tidak dapat terpenuhi, karena jumlah pertumbuhan wisatawan yang berkunjung tidak mencapai $20 \%$. Salah satu strategi yang ditempuh pihak pengelola untuk meningkatkan adalah dengan meningkatkan kualitas produk pariwisata yang dimiliki. Kualitas produk pariwisata menjadi salah satu referensi bagi wisatawan dalam memilih destinasi wisata yang akan dituju yang kemudian dapat mempengaruhi keputusan wisatawan untuk berkunjung. ke sebuah Bale Seni Barli-Kota Baru Parahyangan. MenurutISO-8402 kosa kata kualitas adalah totalitas dari fasilitas dan karakteristik suatu produk atau jasa yang mampu memuaskan kebutuhan, yang tersurat atau tersirat. Dapat disimpulkan bahwa kualitas produk pariwisata merupakan totalitas sebuah produk wisata yang memiliki nilai kumulatif yang baik sehingga dapat memenuhi kebutuhan wisatawan saat melakukan aktivitas wisata. Menurut Buhalis, sebuah produk wisata dikatakan berkualitas apabila 
memenuhi enam aspek utama yang harus dimiliki sebuah destinasi wisata, yaitu attraction, accessibility, amenities, available packages, activities and ancillary services. Keenam komponen tersebut merupakan faktor-faktor yang harus dikelola agar dapat memuaskan wisatawan sekaligus membentuk citra yang positif bagi destinasi tersebut.

Bale Seni Barli Kota Baru Parahyangan sudah memiliki ke enam aspek atribut produk wisata tersebut, seperti terdapat fitur utama yaitu kegiatan seni yang ditawarkan, kemudahan mencapai lokasi, tersedianya fasilitas yang mendukung, tersedia paket-paket wisata yang dapat dipilih wisatawan, aktivitas yang menarik untuk diikuti dan tersedianya pemandu wisata dan instruktur saat menikmati aktivitas wisata. Akan tetapi, perlu dianalisis kembali apakah atribut produk yang dimiliki tersebut telah memenuhi kriteria agar bisa dikategorikan sebagai produk yang berkualitas sehingga mampu menjadi faktor penarik wisatawan untuk berkunjung.

Tujuan dari penelitian ini adalah untuk memperoleh hasil temuan mengenai:

1. Untuk memperoleh temuan mengenai kualitas produk pariwisata di Bale Seni Barli- Kota Baru Parahyangan

2. Untuk memperoleh temuan mengenai keputusan berkunjung wisatawan di Bale Seni Barli-Kota Baru Parahyangan

3. Untuk memperoleh temuan mengenai pengaruh kualitas produk pariwisata terhadap keputusan berkunjung wisatawan di Bale Seni Barli-Kota Baru Parahyangan

Hasil penelitian ini diharapkan dapat bermanfaat dalam bidang akademik, khsusnya dalam kajian ilmu pemasaran pariwisata serta bahan kajian lebih lanjut mengenai kualitas produk pariwisata yang berpengaruh terhadap keputusan berkunjung Kegunaan praktis penelitian ini sebagai kontribusi untuk industri pariwisata, khususnya di Bale Seni Barli-Kota Baru Parahyangan, dalam rangka meningkatan jumlah kunjungan wisatawan sesuai dengan target yang diharapkan.

Berdasarkan latar belakang di atas, maka dapat dirumuskan masalah penelitian sebagai berikut:

1. Bagaimana kualitas produk pariwisata di Bale Seni Barli-Kota Baru Parahyangan

2. Bagaimana keputusan berkunjung wisatawan di Bale Seni Barli-Kota Baru Parahyangan

3. Bagaimana pengaruh kualitas produk pariwisata terhadap keputusan berkunjung wisatawan di Bale Seni Barli-Kota Baru Parahyangan

Tujuan dari penelitian ini antara lain sebagai berikut:

1. Untuk memperoleh temuan mengenai kualitas atribut produk wisata di Bale Seni Barli-Kota Baru Parahyangan 
2. Untuk memperoleh temuan mengenai keputusan berkunjung di Bale Seni Barli-Kota Baru Parahyangan

3. Untuk memperoleh gambaran mengenai pengaruh kualitas atribut produk wisata terhadap keputusan berkunjung di Bale Seni Barli-Kota Baru Parahyangan

Penelitian ini diharapkan secara teoritis bermanfaat dalam pengembangan ilmu dan penelitian dalam bidang displin ilmu Pariwisata khusunya pengembangan wawasan tentang kualitas atribut produk pariwisata terhadap keputusan berkunjung serta memberikan masukan bagi peneliti dalam menggembangkan destinasi pariwisata. Secara praktis hasil penelitian ini diharapkan dapat memberikan masukan bagi pihak pengelola Bale Seni BarliKota Baru Parahyangan dalam meningkatkan wisatawan melalui kualitas atribut produk pariwisata sehingga dapat meningkatkan wisatawan yang berkunjung ke Bale Seni Barli-Kota Baru Parahyangan

\section{Kualitas produk pariwisata}

Produk wisata merupakan keseluruhan pelayanan yang diperoleh dan dirasakan atau dinikmati wisatawan semenjak ia meninggalkan tempat tinggalnya sampai ke daerah tujuan wisata yang telah dipilihnya dan kembali ke rumah di mana ia berangkat semula. Baud-Bovy dalam Oka A.Yoeti (2002:128) mengemukakan bahwa

Produk pariwisata adalah sejumlah fasilitas dan pelayanan yang disediakan dan diperuntukan bagi wisatawan, yang terdiri dari tiga komponen, yaitu sumber daya yang terdapat pada suatu objek wisata, fasilitas yang terdapat di suatu objek wisata, dan transportasi yang membawa dari tempat asalnya ke suatu objek tertentu.

Sedangkan Menurut Suswantoro (2007:75) pada hakekatnya pengertian produk wisata "adalah keseluruhan palayanan yang diperoleh dan dirasakan atau dinikmati wisatawan semenjak ia meninggalkan tempat tinggalnya sampai ke daerah tujuan wisata yang dipilihnya dan sampai kembali kerumah dimana ia berangkat semula."

Menurut Oka A. Yoeti, (2002:211) Produk wisata sebagai salah satu obyek penawaran dalam pemasaran pariwisata memiliki unsur-unsur utama yang terdiri menjadi 3 bagian yaitu:

1. Daya tarik daerah tujuan wisata, termasuk didalamnya citra yang dibayangkan oleh wisatawan

2. Fasilitas yang dimiliki daerah tujuan wisata, meliputi akomodasi, usaha pengolahan makanan, parkir, trasportasi, rekreasi dan lain-lain

3. Kemudahan untuk mencapai daerah tujuan wisata tersebut. 
Fasilitas dan layanan yang ditawarkan oleh sebuah destinasi oleh Buhalis (2000:97) digolongkan kedalam enam kategori dan dapat disebut sebagai enam komponen produk pariwisata, yaitu: attraction, accessibility, amenities, available packages, activities and ancillary services, (atraksi, aksesibilitas, amenitas, paket layanan yang tersedia, aktivitas dan layanan tambahan lainnya yang memberikan kemudahan kepada wisatawan). Dengan terpenuhinya keenam elemen tersebut diharapkan dapat memenuhi kebutuhan wisatawan saat melakukan aktivitas wisata. Konsep tersebut dijabarkan lagi oleh Stankovic dan Dukic (2009:23) sebagai komponen produk pariwisata dari sebuah destinasi yaitu:

1. Atraksi. menurut Swarbrooke (2007:177) Atraksi adalah komponen terpenting dalam sistem pariwisata yang merupakan motivasi utama wisatawan melakukan suatu perjalanan. Atraksi wisata dapat berupa alam, buatan manusia, dibangun untuk tujuan tertentu acara special dan mempunyai nilai sejarah.

2. Aksesibilitas menurut Medlik, 2002 (dalam Ariyanto 2005) menjelaskan bahwa accesable dimaksudkan agar wisatawan domestik dan mancanegara dapat dengan mudah dalam pencapaian tujuan ke tempat wisata. Aksesibilitas tidak hanya tentang alat transportasi saja tetapi juga sarana dan prasarana yang mendukung dalam memudahkan wisatawan dalam mencapai suatu objek wisata.

3. Amenitas dapat dikategorikan menjadi infrastruktur dan suprastruktur. Contoh dari infrastruktur adalah utilities (penerangan listrik, persediaan air minum dan sumber energi), komunikasi dan sarana lain yang memudahkan wisatawan dalam pencapaian dan penggunaan sebuah destinasi. Sedangkan contoh dari suprastruktur adalah restoran, toko dan hiburan.

4. Paket-paket yang tersedia - available packages (berbagai paket yang sudah diatur sebelumnya oleh perantara dan principal)

5. Aktivitas (semua aktivitas yang tersedia di sebuah destinasi, dan apa yang bisa dilakukan wisatawan selama waktu kunjungannya)

6. Layanan tambahan - ancillary services (berbagai layanan tambahan yang digunakan wisatawan seperti bank, mesin atm, rumah sakit, dan sebagainya) Richard Sihite (2000 :145) menyatakan bahwa Sarana penunjang dapat menunjang sarana pokok yang berfungsi bukan saja untuk membuat wisatawan lebih lama tinggal di suatu objek wisata tetapi yang lebih penting adalah untuk membuat wisatawan lebih banyak mengeluarkan uangnya atau membelanjakan uangnya di tempat yang ia kunjungi.

\section{Keputusan Berkunjung}

Menurut Kotler \& Amstrong (2012:133) mengatakan bahwa "Consumer buyer behavior The buying behavior of final consumers-individuals and households that buy goods and services for personal consumption." (Perilaku pembeli konsumen -perilaku pembelian konsumen akhir-individu dan rumah tangga yang membeli barang dan jasa untuk konsumsi pribadi.) Sedangkan 
menurut Kotler \& Amstrong (2012:154) “Purchase decision is The buyer's decision about which brand to purchase." (Keputusan pembelian adalah Keputusan pembeli tentang merek untuk membeli). Keputusan untuk berkunjung timbul karena adanya penilaian objektif atau karena dorongan emosi, keputusan untuk bertindak adalah hasil dari serangkaian aktifitas yang dapat dideskripsikan proses kunjungan. Memahami perilaku pengunjung tidaklah mudah karena pengunjung memutuskan berkunjung tertentu yang berbeda dan sangat bervariasi dalam usia, pendapatan, tingkat pendidikan, dan selera melalui tahap-tahap proses pengambilan keputusan berkunjung,

Menurut Kotler (2011:240) ada enam keputusan atau dimensi yang, yaitu:

1. Pemilihan Produk/Jasa

Bale Seni Barli-Kota Baru Parahyangan harus memusatkan perhatianya kepada orang-orang yang berminat untuk mengunjungi daya tarik wisata yang mereka kelola sehingga wisatawan dapat mengambil keputusan untuk mengunjungi Bale Seni Barli-Kota Baru Parahyangan

2. Pilihan Brand (Merek)

Setiap merek memiliki perbedaan-perbedaan tersendiri, sehingga wisatawan harus memutuskan merek mana yang akan dikunjungi. Dalam hal ini pengelola DTW harus mengetahui bagaimana wisatawan memilih sebuah merek.

\section{Pemilihan Penyalur}

Keputusan wisatawan untuk menentukan penyalur akan selalu berbeda-beda karena berbagai faktor misalnya lokasi yang dekat, harga yang murah, ketersediaan produk dan jasa wisata yang lengkap, kenyamanan melakukan pembelian, keleluasan tempat atau ruang gerak aktivitas, dan sebagainya.

\section{Waktu kunjungan}

Keputusan berkunjung wisatawan bisa dilakukan dalam pemilihan waktu yang berbeda-beda, sesuai dengan kapan produk tersebut dibutuhkan.

\section{Jumlah kunjungan}

Wisatawan dapat mengambil keputusan tentang seberapa banyak produk yang akan dikunjunginya pada suatu saat. Kunjungan mungkin dilakukan lebih dari satu kali.

6. Metode Pembayaran

Wisatawan dalam mengunjungi suatu daya tarik wisata dihadapkan pada beberapa pilihan metode pembayaran, hal tersebut dimaksudkan agar wisatawan diberikan 
pilihan dalam melakukan pembayaran, baik secara tunai maupun menggunakan kartu kredit.

Seperti yang diungkapkan oleh Anderson, E. W; Fornell, C and Lehmann, D.R, 1994, bahwa Kuallitas produk merupakan salah satu faktor pembentuk persepsi kepuasan konsumen. Dalam pandangan konsumen, nilai suatu produk merupakan kualitas produk yang dinikmati konsumen dengan pengorbanan sejumlah uang atau sumber daya yang lain (Oliver, 1997 dalam Andreasson dan Lindestad, 1998). Artinya bahwa kualitas produk mempengaruhi persepsi wisatawan saat memilih sebuah DTW untuk dikunjungi, begitu pula yang dikatakan Engel et.al (1994:356) Atribut produk merupakan karakteristik atau sifat suatu produk umumnya mengacu pada karakteristik yang berfungsi sebagai bahan evaluasi selama pengambilan keputusan pembelian konsumen. Kemudia Fandy Tjiptono (2005:198) mengatakan bahwa atribut produk adalah unsur-unsur produk yang dipandang penting oleh konsumen dan dijadikan dasar pengambilan keputusan pembelian akan produk.

\section{METODE PENELITIAN}

Dalam penelitian ini kualitas atribut produk wisata berperan sebagai variabel bebas (independet variable) yang terdiri attraction, accessibility, amenities, available packages, activities and ancillary services,. Sedangkan keputusan berkunjung sebagai variabel terikat (dependent variable) yang terdiri dari pilihan produk, pilihan merek, jumlah kunjungan, waktu berkunjung, metode pembayaran. Metode yang digunakan adalah cross sectional method. Berdasarkan variabel-variabel yang akan diteliti, maka jenis penelitian ini adalah penelitian deskriftif dan penelitian verifikatif. Metode penelitian yang digunakan dalam penelitian ini adalah explanatory survey. Pengoperasian variabel dari kedua variabel yang dijadikan objek pada penelitian ini menggunakan skala ordinal.

Jenis sumber data yang digunakan dalam penelitian ini dikelompokan ke dalam dua kelompok data yaitu data sekunder dan data primer. Populasi yang akan digunakan dalam penelitian ini adalah populasi dari wisatawan yang berkunjung ke Bale Seni Barli Kota Baru Tahun 2013 Parahyangan yaitu sebesar 11.623 wisatawan. Berdasarkan rumus Slovin, jumlah sampel minimal yang diteliti adalah berjumlah 100 responden. Teknik sampling yang digunakan dalam penelitian ini salah satunya adalah teknik systematic random sampling atau teknik pengambilan sampel acak sistematis untuk populasi yang bergerak. Teknik pengumpulan data menggunakan angket, wawancara, studi dokumentasi, dan studi literature. Rancangan teknik analisis data menggunakan rancangan analisis deskriptif dan analisis verifikatif. Penelitian ini menggunakan analisis data regresi linier sederhana atau melakukan prediksi (taksiran). 


\section{HASIL DAN PEMBAHASAN}

1. Berdasarkan uji korelasi pada penelitian ini bahwa pengaruh kualitas produk terhadap keputusan berkunjung yaitu sebesar 69\%, dan sisanya yaitu sebesar $31 \%$ dipengaruhi oleh faktor lain yaitu bahwa antara kualitas produk dengan keputusan berkunjung memiliki hubungan yang cukup kuat. Hal ini menunjukan bahwa ketika kualitas produk ditingkatkan, maka keputusan berkunjung wisatawan ke Bale Seni Barli Kota Baru Parahyangan pun akan ikut meningkat.

2. Berdasarkan pengujian hipotesis terdapat hubungan positif antara kualitas produk terhadap keputusan berkunjung wisatawan dengan nilai Sig. sebesar $0,008<0,05$. Sehingga dapat dikatakan bahwa Ho di tolak dan Ha diterima.

Hal tersebut menunjukan bahwa Bale Seni Barli-Kota Baru Parahyangan sudah memiliki atribut produk wisata yang dapat dikategorikan berkualitas, antara lain atraksi yang menarik, yaitu menawarkan berbagai kegiatan seni, seperti apresiasi seni (galeri, studio lukis, dan patung), menyelenggarakan workshop bagi siswa-siswi TK, SD, SMP, SMA, dan Umum dengan berbagai kegiatan yang interaktif dan menyenangkan yang dilengkapi dengan permainan angklung interaktif. Atraksi yang dimiliki Bale Seni Barli-Kota Baru Parahyangan memiliki tingkat keunikan yang tinggi, karena menawarkan wisata seni yang mengedukasi. Para wisatawan yang berkunjung akan ditawarakan berbagai paket wisata berupa workshop yang akan menjadi pengalaman baru mereka dalam membuat karya seni. Hal tesebut menjadi sebuah keunikan tersendiri karena jarang terdapat DTW yang menawarkan atraksi yang serupa. Sehingga wisatawan mendapatkan value added saat berkunjung ke Bale Seni Barli-Kota Baru Parahyangan, walaupun tujuan utamanya adalah berwisatawa, wisatawan juga diedukasi untuk mengenal bahkan ikut mencoba membuat berbagai karya seni.

Bale Seni Barli-Kota Baru Parahyangan juga relatif mudah untuk diakses wisatawan. Walaupun terletak di Kabupaten Bandung, tepatnya di Kota Baru Parahyangan, Padalarang, Bale Seni Barli-Kota Baru Parahyangan mudah diakses oleh wisatawan yang berasal dari Kota Bandung maupun Luar Kota Bandung, karena terdapat transportasi umum yaitu Bus Damri yang rute perjalanannya melewati lokasi Bale Seni Barli-Kota Baru Parahyangan. Jalan menuju lokasi juga dalam kondisi baik, dan wisatawan dapat dengan mudah menemukan lokasi karena terdapat signboard yang menunjukan keberadaan Bale Seni Barli-Kota Baru Parahyangan. Masyarakat sekitar dan para pengemudi transportasi umum juga sudah mengetahui keberadaan Bale Seni Barli-Kota Baru Parahyangan sehingga wisatawan dengan mudah dapat mendapatkan informasi apabila kebingungan mencari lokasi DTW. Bale Seni Barli-Kota Baru Parahyangan juga menawarkan paket-paket wisata yang beraneka ragam antara lain Fun with 
Science and Art terdiri dari 4 program, Art Play terdiri dari 3 program, dan Science on The Move terdiri dari 3 program. Setiap paket memiliki nama yang unik dan variatif untuk membedakan kegiatan dari tiap paket yang ditawarkan yang menjadi ciri khas dari setiap paket tersebut. Wisatawan dihadapkan pada beberapa pilihan paket wisatawan yang menarik, sehingga mereka dapat memilih paket wisata sesuai dengan minat dan bakat.

Dari sisi amenitas, tidak dapat dipungkiri bahwa wisatawan akan kesulitan menemukan fasilitas akomodasi seperti hotel dan restoran, sehingga wisatawan yang datang secara individu akan kesulitan untuk menemukan restoran maupun hotel. Berbeda dengan wisatawan yang berkunjung bersama rombongan, karena biasanya kebutuhan tamu rombongan sudah diatur oleh travel agent baik untuk makan maupun tempat menginap. Tidak tersedianya fasilitas menginap dikarenakan Bale Seni Barli-Kota Baru Parahyangan merupakan DTW yang menawarkan paket-paket wisata yang durasi waktu aktivitasnya selesai dalam satu hari sehingga jarang sekali wisatawan yang sengaja datang berkunjung untuk sekaligus menginap di sekitar lokasi DTW. Sedangkan layanan tambahan yang disediakan oleh Bale Seni Barli Kota Baru Parahyangan adalah tersedianya para pemandu dan instruktur yang akan membimbing wisatawan saat mengikuti berbagai workshop seperti membuat batik celup ikat, melukis di media kaca, gerabah dan kanvas dan ikut memainkan angklung interaktif. Wisatawan juga dapat membawa hasil karya seni yang dibuat sendiri untuk dibawa pulang. Kehadiran para pemandu dan instruktur ini dapat memastikan bahwa seluruh wisatawan yang datang dapat menikmati dan mengikuti seluruh rangkaian kegiatan yang ditawarkan dengan baik.

Berdasarkan analisis diatas dapat disimpulkan bahwa dilihat dari atribut produk wisata yang tersedia, Bale Seni Barli-Kota Baru Parahyangan mampu memenuhi semua elemen yang harus dimiliki sebuah DTW dan dinilai berkualitas, sehingga mampu menarik wisatawan untuk berkunjung ke Bale Seni Barli-Kota Baru Parahyangan. Seperti yang diungkapkan oleh Hainim (2000: 2) bahwa Fasilitas dan/atau aktivitas wisata dapat berfungsi ganda yaitu sebagai atraksi wisata yang mampu menarik wisatawan/pengunjung untuk- datang mengunjunginya melalui produk yang dimiliki dan ditawarkannya. Sedangkan Basu Swasta (1997: 49)mengungkapkan bahwa Perusahaan harus mengetahui kegiatan pengumpulan informasi dan evaluasi dari pembeli dan menunjang proses belajar pembeli terhadap atribut produk. 


\section{SIMPULAN}

Berdasarkan hasil penelitian yang telah dilakukan dengan menggunakan analisis deskriptif dan verifikatif antara kualitas produk dan keputusan berkunjung wisatawan maka dapat ditarik kesimpulan sebagai berikut:

1. Berdasarkan Keenam aspek yang dianalisisi, dapat diketahui bahwa aspek yang paling tinggi pada kualitas atribut produk wisata di Bale Seni Barli- Kota Baru Parahyangan adalah atraksi, aktivitas dan paket wisata. Karena Bale Seni Barli memiliki atraksi wisata yang unik dan unggul yang tidak dimiliki DTW lain, dengan keunikannya tersebut juga didukung oleh aktivitas wisata yang ditawarkan, dimana wisatawan mendapatkan pengalaman menarik untuk membuat karya seni hasil karya sendiri yang dibuat dengan bantuan dan arahan dari para pemandu dan instruktur. Sehingga dapat dipastikan semua wisatawan mendapatkan pengalaman yang tidak terlupakan saat terjun langsung membuat sebuah karya seni. Oleh karena itu peran pemandu dan instruktur sangatlah besar dalam menciptakan pengalaman berwisata yang menyenangkan, sehingga para pemandu dan instruktur dituntut untuk dapat memberikan panduan dan arahan yang menarik kepada wisatawan. Selain itu minat wisatawan terwadahi oleh banyaknya pilihan paket wisata yang ditawarkan. Tingginya tanggapan wisatawan terhadap atraksi,aktivitas dan tersedianya paket-paket wisata menjadi peluang bagi Bale Seni Barli-Kota Baru Parahyangan untuk terus berinovasi dalam membuat atraksi wisata yang lebih menarik. Memperkaya bergam aktivitas yang bisa dilakukan oleh wisatawan dan menyiapkan paketpaket wisata baru yang tidak dapat wisatawan temukan di tempat lain. Aspek kualitas produk pariwisata yang paling rendah kualitasnya adalah amenitas. Hal tersebut terjadi karena tidak tersedianya restoran maupun hotel sebagai sarana akomodasi dalam rangka memenuhi keinginan dan kebutuhan wisatawan. Hal tersebut dikarenakan seluruh paket wisata yang ditawarkan kepada wisatawan merupakan paket yang dirancang selesai dalam satu hari. Oleh karena itu pihak pengelola dapat melihat potensi tingginya minat wisatawan untuk berwisata lebih lama dengan menyediakan paket wisata yang lebih panjang durasi waktu pelaksanaanya, atau membangun aktraksi lain yang dapat dimanfaatkan wisatawan dalam rangka menghabiskan waktu senggangnya lebih lama di Bale Seni Barli-Kota Baru Parahyangan. Berdasarkan analisis diatas dapat disimpulkan bahwa dilihat dari atribut produk wisata yang tersedia, Bale Seni Barli-Kota Baru Parahyangan mampu memenuhi semua elemen yang harus dimiliki sebuah DTW dan dinilai berkualitas, sehingga mampu menarik wisatawan untuk berkunjung ke Bale Seni Barli-Kota Baru Parahyangan.

2. Berdasarkan hasil pengolahan data diketahui bahwa penilaian tertinggi yang diberikan wisatawan pada variabel keputusan berkunjung adalah pada point kemudahan pada saat melakukan pembayaran, sedangkan penilaian terendah pada point waktu kunjungan pada saat weekday/hari kerja. Hal tersebut dikarenakan Bale Seni Barli-Kota Baru Parahyangan hanya menerima tamu pada hari kerja, sehingga wisatawan yang hanya memiliki waktu senggang di 
hari libur tidak dapat menikmati atraksi dan aktivitas wisata seni di Bale Seni Barli-Kota Baru Parahyangan.

Berdasarkan rata-rata penilaian secara keseluruhan, responden memberikan penilaian baik dengan nilai sebesar $73,48 \%$ pada penilaian keputusan berkunjung wisatawan ke Bale Seni Barli Kota Baru Parahyangan. Berdasarkan Skala Likert termasuk pada kategori cukup baik.

3. Berdasarkan pengujian hipotesis diketahui bahwa kualitas produk berpengaruh secara signifikan terhadap keputusan berkunjung. Hal ini menunjukan kualitas produk dilakukan dengan baik di Bale Seni Barli Kota Baru Parahyangan. Berdasarkan uji korelasi pada penelitian ini diketahui bahwa antara kualitas produk dengan keputusan berkunjung memiliki hubungan yang cukup kuat. Hal ini menunjukan bahwa apabila kualitas produk ditingkatkan, maka keputusan berkunjung wisatawan ke Bale Seni Barli Kota Baru Parahyangan pun akan cenderung bernilai positif. Berdasarkan uji korelasi pada penelitian ini diketahui bahwa antara kualitas produk dengan keputusan berkunjung memiliki hubungan yang cukup kuat. Hal ini menunjukan bahwa apabila kualitas produk ditingkatkan, maka keputusan berkunjung wisatawan ke Bale Seni Barli Kota Baru Parahyangan pun akan cenderung bernilai positif.

\section{DAFTAR PUSTAKA}

Anderson, E. W, Fornell, C and Lehmann, D.R, (1994). Customer Satisfaction, Market Share, and Profitability: Finding From Sweden, Journal of Marketing, Vol.58, p.53-56

Ariyanto. (2005). Ekonomi Pariwisata, Penerbit Rineka Cipta, Jakarta.

Basu, S. (1997). Pengantar Pariwisata dan Atribut Produk. Jakarta: PT.Gramedia

Buhalis, D. (2000), Marketing the competitive destination of the future,

Tourism Management, Vol. 21, pp. 97-116

Engel, et.al. (1994) Customer Behavior $8^{\text {th }}$ Edition. Dryden Press. Horcout Brace College Publisher

Fandy, T. (2005). Strategi Pemasaran. Yogyakarta: Andi Publisher

Kotler, P \& Keller, L. (2011). Marketing Management, 14e, Global Edition, Pearson Education Limited, England

Kotler, P \& Amstrong, G. (2012). Principles of Marketing. New Jersey: Prentice Hall.

Sihite, R. (2000). Tourism Industry (kepariwisataan). Surabaya: SlC. 
Stanković, Ljiljana., Đukić, Suzana., (2009). Challenges Of Strategic Marketing of Tourist destination Under The crisis Conditions, Facta Universitatis Series: Economics And OrganizationVol. 6, No 1, 2009, page 23

Suswantoro. (2007). Dasar - dasar pariwisata. Yogyakarta :CV Andi Offset.

Swarbrooke, J, \& Horner, S. (2007). Consumer Behaviour in Tourism. (second ...

Yoeti, O, A. (2002). Perencanaan Strategis Pemasaran Daerah. Tujuan Wisata. Penerbit PT. Pradnya Paramita, Jakarta. ISO 8402 (Quality Vocabulary) 